\title{
Embracing the eye of the Apple: On anthropology, theology and technology
}

\begin{tabular}{|c|c|}
\hline $\begin{array}{l}\text { Author: } \\
\text { Daniël P. Veld }\end{array}$ & $\operatorname{man}^{1}$ \\
\hline $\begin{array}{l}\text { Affiliation: } \\
{ }^{1} \text { Department } \\
\text { and Historical } \\
\text { Faculty of The } \\
\text { Religion, Univ } \\
\text { Pretoria, Pret } \\
\text { South Africa }\end{array}$ & $\begin{array}{l}\text { f Systematic } \\
\text { Theology, } \\
\text { ology and } \\
\text { ersity of } \\
\text { oria, }\end{array}$ \\
\hline $\begin{array}{l}\text { Research Proj } \\
\text { Project Leade } \\
\text { Project Numb }\end{array}$ & $\begin{array}{l}\text { ect Registration: } \\
\text { r: D.P. Veldsman } \\
\text { er: } 01224719\end{array}$ \\
\hline $\begin{array}{l}\text { Description: } \\
\text { This research } \\
\text { project, 'Relig } \\
\text { from an evolu } \\
\text { perspective', } \\
\text { Prof. Dr Danie } \\
\text { Department o } \\
\text { and Historical } \\
\text { Faculty of The } \\
\text { Religion, Univ } \\
\text { Pretoria. }\end{array}$ & $\begin{array}{l}\text { is part of the } \\
\text { ous Experience } \\
\text { tionary } \\
\text { lirected by } \\
\text { Veldsman, } \\
\text { f Systematic } \\
\text { Theology, } \\
\text { ology and } \\
\text { ersity of }\end{array}$ \\
\hline $\begin{array}{l}\text { Correspondin } \\
\text { Daniël Veldsm } \\
\text { danie.veldsma }\end{array}$ & $\begin{array}{l}\text { g author: } \\
\text { an Mail, } \\
\text { in@up.ac.za }\end{array}$ \\
\hline $\begin{array}{l}\text { Dates: } \\
\text { Received: } 11 \\
\text { Accepted: } 14 \\
\text { Published: } 28\end{array}$ & $\begin{array}{l}\text { Apr. } 2019 \\
\text { Aug. } 2019 \\
\text { Nov. } 2019\end{array}$ \\
\hline $\begin{array}{l}\text { How to cite th } \\
\text { Veldsman, D.P } \\
\text { 'Embracing th } \\
\text { Apple: On ant } \\
\text { theology and } \\
\text { HTS Teologies } \\
\text { Theological St } \\
\text { a5498. https:/ } \\
\text { 10.4102/hts.V }\end{array}$ & $\begin{array}{l}\text { is article: } \\
\text {., 2019, } \\
\text { e eye of the } \\
\text { hropology, } \\
\text { technology', } \\
\text { e Studies/ } \\
\text { udies } 75(1) \text {, } \\
\text { /doi.org/ } \\
75 i 1.5498\end{array}$ \\
\hline $\begin{array}{l}\text { Copyright: } \\
\text { (c) 2019. The A } \\
\text { Licensee: AOS } \\
\text { is licensed unc } \\
\text { Creative Comr } \\
\text { Attribution Lic }\end{array}$ & $\begin{array}{l}\text { Iuthors. } \\
\text { IS. This work } \\
\text { der the } \\
\text { nons } \\
\text { ense. }\end{array}$ \\
\hline Read online: & \\
\hline 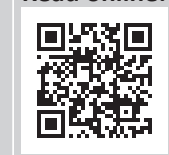 & $\begin{array}{l}\text { Scan this QR } \\
\text { code with your } \\
\text { smart phone or } \\
\text { mobile device } \\
\text { to read online. }\end{array}$ \\
\hline
\end{tabular}

\section{Author:}

Affiliation:

${ }^{1}$ Department of Systematic and Historical Theology, Faculty of Theology and Pretoria, Pretoria,

Research Project Registration: Project Leader: D.P. Veldsman Project Number: 01224719

Description: project, 'Relig from an evolutionary perspective', directed by Prof. Dr Danie Veldsman pystema Faculty of Theology and Religion, University of Daniël Veldsman Mail,

Dates: Accepted: 14 Aug. 2019 How to cite this article: Veldsman, D.P., 2019, 'Embracing the eye of the Apple: On anthropology, theology and technology', Theological Studies 75(1) a5498. https://doi.org/

Copyright: Licensee: AOSIS. This work is licensed under the Creative Commons Attribution License.
The playful re-working of the idiomatic expression 'the apple of my eye' to the 'eye/I of my Apple' provides the answer to the question on technology, emphasising its importance for societies, specifically the South African society, and embodied personhood, and at the same time its determinative contextual character. The answer to the question on technology firstly takes as the vantage point a few personal comments by the author in relation to the question at hand. Secondly, brief remarks on technology and approaches to the question are made before the focus on ethics is explicated and motivated. Lastly, a deep concern is identified and is poignantly described as the probable wicked technologisation of the African soul.

Keywords: Technology; Fourth Industrial Revolution; Ethics; Theology and technology; The Bartimaeus effect.

\section{Introduction}

The well-known idiomatic expression apple of my eye represents the semantic background to the title of the article. However, its playful reworking to eye of my Apple is done as a contextual translation of the expression to a technological context. Within the latter context, an important further adjustment is needed, namely, to add an 'I' to the expression because the two together are of significant importance for my exposition to follow. The revised title will then be: Embracing the eye /I of the Apple.

The modification to 'eye or I' has a twofold significance. It acknowledges the unavoidable and determinative contextuality of my (read: all!) perspective(s). I always speak from somewhere to somebodies at a specific time and place about something for some or the other reason(s). 'My speaking' thus always carries with it geographical, sociocultural, philosophical and psychological (and even more!) traits. I am a white South African male who engages theologically from a Christian perspective in our historical-social context with the very important issue of technology. By adding the ' $\mathrm{I}$ ', the implicit hermeneutical privileging of the eye is relativized as we experience and interpret our life-worlds (perspectives) with all our senses. This is the double significance that I want to be conveyed by the eye or I.

The word Apple in the title simply represents, in a metaphoric sense, technology. I chose Apple because it is indeed an influential brand when it comes to technology. I expand its metaphoric use as a word into the idiomatic expression 'apple of my eye' to emphasise 'importance' or something that is held dear, perhaps even more emphatically; something that 'is' not only very important but even constitutive or/and decisive for my very being as person, for my or our personhood. This article is about technology and specifically its importance within our societies. If we are then talking about technology, what precisely are we talking about? In an interview with bishop Kallistos Ware on the relationship of technology with science and religion, he states in very general terms that technology can be seen as a descriptive term for applying sciences in practical ways, producing particular kinds of machines or gadgets that people can use (Ware 2017:20). I think more must be said. Technology, from the Greek word techne, meaning craft, art and knowledge, can perhaps more aptly be described as consisting of three elements, namely, tools (i.e. the machines, chemicals, instruments), processes (i.e. techniques and methods) and social contexts (i.e., the very different contexts in which it is used and developed).

In what follows, I will firstly make a few personal comments on my own relation to the question at hand. Secondly, brief remarks on technology and approaches to the very question must subsequently suffice before I explain, thirdly, my choice to focus on the question of ethics and lastly my concern for what I will call: the probable wicked technologisation of the African soul.

Note: SASRF 2019, sub-edited by Cornel du Toit (University of South Africa) and Wesel Bentley (University of South Africa). 


\section{Really?}

When I sat down with two other colleagues of the planning committee at the beginning of the year to discuss possible themes for the South African Science and Religion Forum (SASRF) conference for this year, I was not very impressed when we ended up with the choice for technology. Really? The title we had formulated for the conference was original and good: Do you know who I am? I was not very enthusiastic about the choice for technology. Surely, I thought, there are a number of other more exciting, important and relevant topics for us to pursue in the South African context. However, I changed my mind very soon after reading just a few recent articles and short overviews from a number of encyclopaedias on technology. It did not take long to be completely convinced of the actuality and the deep probing importance of the topic at hand: especially for Africa, and for us in South Africa. Let me elaborate on what changed my mind.

A statement such as the very recent initial declaration of the Parliament of World Religions strengthened - as a statement my awareness of the importance of serious reflection on the topic. It captures in simple but straightforward formulation what is at stake. It states (Council 1993):

Today, we possess sufficient economic, cultural and spiritual resources to introduce a better global order. But old and new ethnic, national, social, economic and religious tensions threaten the peaceful building of a better world. We have experienced greater technological progress than ever before, yet we see the world over that poverty, hunger, death of children, unemployment, misery and the destruction of nature have not diminished but rather have increased. Many people are threatened with economic ruin, social disarray, political marginalisation, ecological catastrophe and national collapse. (p. 7)

Indeed! Greater technological progress than ever before, yet even greater misery, economic ruin and ecological catastrophes. Or as Jeffrey Shaw (2018) alarmingly puts it in his published dissertation as a critique of the Roman Catholic Church by Thomas Merton:

The whole massive complex of technology, which reaches into every aspect of social life today, implies a huge organization of which no one is really in control, and which dictates its own solutions irrespective of human needs or even reason. (p. 152)

Reaches into every aspect of social life today? Yes, it does. Therefore (Schwenger 2016):

The importance of technology in our time can hardly be overestimated. Technology is ubiquitous and all areas of life are influenced by it, such as work processes, mobility, relationships (especially the realm of communication), leisure activities and health. (p. 44)

Its great importance is strongly emphasised from the first to the last page (it is mentioned 19 times!) of the influential Agenda 2063 that has been compiled by the African Union for an Africa where 'all is not well'. Deeply conscious that
Africa stands at the crossroads, and determined to transform the continent and ensure irreversible and universal change of the African condition, it states as Aspiration 1 the following:

We aspire that by 2063, Africa shall be a prosperous continent, with the means and resources to drive its own development, with sustainable and long-term stewardship of its resources and where (African Union 2015):

- African people have a high standard of living, and quality of life, sound health and well-being.

- Well educated and skilled citizens, underpinned by science, technology and innovation for a knowledge society is the norm and no child misses school due to poverty or any form of discrimination. (p. 2)

\section{It also states that (African Union 2015):}

By 2063, African countries will be amongst the best performers in global quality of life measures. This will be attained through strategies of inclusive growth, job creation, increasing agricultural production; investments in science, technology, research and innovation; gender equality, youth empowerment and the provision of basic services including health, nutrition, education, shelter, water and sanitation. (p. 3)

The last societal example, and perhaps the most important of all, is the emphasis and description of the so-called Fourth Industrial Revolution that captures the idea of the confluence of new technologies and their cumulative impact on our world. As a 'perfect storm of technologies' that is paving the way for transformative changes in the way we live and is radically disrupting - at a whirlwind pace - almost all sectors of life, it is insightfully described as a blurring of boundaries between the physical, digital and biological worlds (McGinnes 2018). It is a fusion of technologies with the essential features of:

- Digitisation: making everything, anything and anywhere computer readable and processable.

- Interconnectivity: everyone or everything talking to everyone or everything.

- Virtualisation: being present and delivering on an ongoing basis, anything, anywhere, anytime, anyhow and for anyone.

- Automation: performing a process or practice, and taking decisions and actions through technological means - for example, robotics, artificial intelligence, $3 \mathrm{~d}$ printing, nano-technology with no or minimum human mediation.

- Smart: generating data from everything or anyone, affecting machine learning through real time, in-time feedback and/or turning data into intelligence through decision-making algorithms in order to take focussed real-time, in time, validated and predictive action.

The Fourth Industrial Revolution is clearly driven by at least five technological enablers! Its alarming relevance and actuality overwhelmed me. I completely underestimated its crucial and much needed importance. This fact was stated and confirmed in general terms in the Stanford Encyclopedia in a lengthy and good introductory article on technology (Franssen, Lokhorst \& Ibo 2018): 
It is largely by technology that contemporary society hangs together. It is hugely important not only as an economic force but also as a cultural force. (p. 1)

In his short article "The "fourth industrial revolution": Potential and risks for Africa', Ross Harvey (2017) of the South African Institute of International Affairs formulates a brief wake-up call:

There are serious advantages to being a first mover in technology. Governments should be building clear strategies that entail all the benefits of a fourth industrial revolution. If not, they risk being left behind. (n.p.)

Two hugely popular social-technological examples can be mentioned in this context. Facebook - as Dave Yauk (2018) remarks - has already turned friendship into a number, and Twitter has already turned poetry into a hashtag. In his critical comments on the brand name Apple and the valuation of the Apple Watch according to Tim Cook as the 'most personal device we've ever created', Yauk asks, 'is Apple now turning knowing someone into something more closely resembling adornment, a piece of jewellery? Are "persons" now only for display?' Yauk (2018) therefore urges the reader:

We must think long and hard about the words we are using to describe things, and more significantly, how we use technologies to form our lives and thus our ideas, and in what manner we allow our hearts to depend onsuch definitions, conceptualizations, and at heart: such things. (n.p.)

I was immediately and deeply convinced to think long and hard with others on technology as a contemporary societal force. I could very much identify with the words of the former aerospace engineer Michael Burdett, now Research Fellow in Religion, Science and Technology at Wycliffe Hall, Oxford, in an interview in which he remarks (Burdett 2017):

(I)t's a really new area (that is, the theology of technology DPV) that is taking off in theological ethics and science and religion. When I first started about a decade ago there were just a handful of likeminded people who saw that technology was impacting many domains of our existence: gene editing tools were promising designer babies, people were beginning to spend their lives mediated more by information media than ever before and the internet and sophisticated ideologies like transhumanism were growing rapidly. This technological growth and its impact on our lives, I'm sure we all understand, is only getting more sophisticated and intimate. I noticed then that there was a decided lack of thoughtful theological reflection on these technological changes and I figured I ought to do what I could to fill the gap since I've both created this technology and I'm trained as a theologian. (pp. 4, 16)

At this point, I must emphasise: I have only scratched the surface of the topic! I have not done justice at all to many facets and dimensions of the issues that come into play in the wide-ranging and very comprehensive discourses on technology. For the sake of my argument to follow, it must suffice. I subsequently, however, will mention and discuss a few, and finally raise an issue which dawned on me the longer I was immersed in the sea of interpretations and views on technology. An issue, which I will ultimately call the probable wicked technologisation of the African soul.

\section{On the I's and the Apples If one is to approach the topic of technology, vast reflective fields lie in front of the interpreter}

There is literature on:

- Historical developments, mostly starting with Greek interpretations stretching back to Aristotle and Plato. Four themes catch the reader's eye that have developed from Ancient Greece, namely, that (1) technology learns from or imitates nature ${ }^{1}$; (2) there is a fundamental ontological distinction between natural things and artefacts; (3) the ontological distinction can be understood from Aristotle's doctrine of the four causes (material, formal, efficient and final); and (4) a wide-spread use of technological imagery (especially with Plato and Aristotle) for expressing their belief in the rational design of the universe (cf. Franssen et al. 2018).

- The philosophy of technology and its social-ethical impact on society and culture.

- The more recent development of a branch within the field that is concerned with technology itself and that aims to understand both the practice of designing and creating artefacts (in a wide sense, including artificial processes and systems) and the nature (metaphysical issues) of the things so created (cf. Franssen et al. 2018).

- The scope and the agenda for ethics of technology are mostly determined by the conceptualisation of technology. Is it merely a neutral tool? Does it represent a worldview? Is it simply a historical necessity? These questions developed into more dense understandings of technology as a political phenomenon, ${ }^{2}$ as a social activity, as a cultural phenomenon, ${ }^{3}$ as a professional activity and as a cognitive activity.

- Two trends developed concurrently with the conceptualisation process, namely, a move away from technological determinism and the assumption that technology is a given self-contained phenomenon, which develops autonomously to an emphasis on technological development being a result of choices (although not necessarily the intended result). The other is a move away from ethical reflection on technology as such to ethical reflection of specific technologies and to specific phases in

1.Franssen et al. (2018) state: 'Democritus - for example - held the view that housebuilding and weaving were first invented by imitating swallows and spiders building
their nests and nets, respectively. Aristotle supported this view but added that art in their nests and nets, respectively. Aristotle supported this view but added that art in
some cases completes what nature cannot bring to a finish'. In an article by Moosa some cases completes what nature cannot bring to a finish'. In an article by Moosa
(2016:369) on historical developments within Muslim circles, he states: 'While our (2016:369) on historical developments within Muslim circles, he states: 'While our
knowledge of the history of Muslim technology is still at its infancy, from the materials available it appears that craftsmen who developed technology grasped both the metaphysical dimension and the empirical dimension of their craft. They could, for instance, imagine technological crafts as the Divine revealing the "secrets of His wisdom to the earths" as a sign of divine dominion and sovereignty. And yet they could also simultaneously adhere to the protocols of empirical observation, testing and experimentation'.

2.Political approaches conceive of technology as a political phenomenon, that is, as a phenomenon that is ruled by and embodies institutional power relations between people.

3.Cultural approaches conceive of technology as a cultural phenomenon that influences our perception of the world. 
the development of technology. Both trends together have resulted in an enormous increase in the number and scope of ethical questions that are asked about technology (cf. Franssen et al. 2018).

- The relationships between technology and science, and technology and religion. How are these relationships to be seen and construed? Is it after all important to relate these very fields to each other?

- Specific themes have been highlighted in the recent discourses on technology such as the centrality of design (as decision-making) to technology; the neutrality thesis ${ }^{4}$ (that has been severely criticised during the 20th century); technological fixing; de-sacralisation of technology; the technological future; the ethics of human enhancement; artificial intelligence, transhumanism and humans as informational beings.

Given the wide range of reflective fields and themes that the interpreter encounters, I have chosen to focus only on the question of ethics and technology, ultimately asking how technology can be ethically valued in the South African society and the implied responsibility that follows from such an evaluation.

\section{The 'haves', the 'have nots' and 'never will haves' in the South African society}

In a recently published interview, the English theologian Kallistos Ware ${ }^{5}$ (2017) said:

All technology is going to affect people, one way or the other. But there comes a point where the effect is unacceptable because it is making this world more difficult for other human beings to live in. (p. 24)

What does the 'world' look like if it is interpretively translated as the South African society? Not good. In a country of 55 million people, about 30 million South Africans are classified as poor, that is, more than half of the population. The National Income Dynamics Study (NIDS) identified five main social classes, namely, the elite, the stable middle class, the vulnerable middle class, the transitory poor and the chronic poor. Only one in four South Africans is part of either the secure middle class or the elite. Altogether $14 \%$ fall into the category of vulnerable middle class and about $13 \%$ could be classified as part of the transitory poor. The rest - about half of the population - are chronically poor, with scant chance of moving into the middle class. Perhaps, even worse: they are likely to become poorer in the future.

How will technology affect the South African society, given their bleak economic status if one is to accept as stated earlier in the article: It is largely through technology that contemporary society is bound together. It is hugely important not only as an economic force but also as a cultural force. And, if this force is creating not only a deep divide

4.The neutrality thesis holds that technology is a neutral instrument that can be put to good or bad use by its users.

5.Kallistos Ware is an English bishop and theologian. He has held, since 1982, the titular Bishopric of Diokleia within the Eastern Orthodox Church under the Ecumenical Patriarchate of Constantinople. between the 'haves' and the 'have nots', but securing a growing 'never will haves', what is the ethical responsibility that must find expression in such a society? ${ }^{6}$

To add some 'have nots 2018' statistics: $14 \%$ of South Africans live in informal settlements; the unemployment rate increased to $27.2 \%$, that is, 29 million; $47 \%$ have conduit water in their dwellings; $11 \%$ are still without electricity and $17.4 \%$ are covered by a South African medical scheme. This means that only 9.5 million South Africans have access to private medical care while more than 44 million do not; there is one practising public doctor per 4219 people; about $10.5 \%$ of all South Africans have access to the Internet, or 4.59 million people, over a third of them - the majority - aged between 18 and 29 years. The country has 5.3 million personal computer users, making up $11 \%$ of the total population; there are 21 million Internet users, the vast majority of which are mobile users. And so I can continue.

The crucial point is: It is a society that is in the grip of an increasing 'never will haves'. And the deep question is: What role will technology play in the process?; what ethical responsibilities are here at stake in a context where hoping for some(things) are beyond attainable possibilities? In short:

Will technological developments in the South African society bring about a totalising worldview that is inherently dehumanising? Or more dramatically formulated: Will it bring about the wicked technologisation of the African soul?

I turn to this question.

\section{The probable wicked technologisation of the African soul}

It is strongly and widely debated whether technological developments are neutral. It is argued that:

- There are two sides to the arguments, given the understandings or - better formulated - conceptualisations of technology in the hands and minds of homo technicus (no longer homo sapiens!). They change worldviews; they dominate cultures and lifestyles; for Heidegger (1977) it is a way of thinking, but then new thinking distinct from nature.

- It is very often not a 'blessing' (Padgett 2005:578). It rather begins - in reference to the critical remarks by Jacques Ellul - to function as a substitute religion in which Technique is the new sacred, the locus of meaning and value, the object of adoration and sacrifice and the hope of salvation (Gill 1998:155).

- Modern theology unavoidably possesses a certain amount of agency (Herzfeld 2009:6). The question that

6.McGinnes (2018:n.p.) elaborates insightfully: New technologies threaten to amplify current inequalities, both within and between countries. Mining - typically a large employer - may become more characterised by keyhole than open heart surgery, to borrow a medical metaphor. That means driverless trucks and robots, all fully digitised, conducting non-invasive mining. A large proportion of the nearly 500000 people employed in South African mining alone may stand to lose their jobs. Rising inequality and income stagnation are also socially problematic. Unequal societies tend to be more violent, have higher incarceration rates, and have lower levels of life expectancy than their more equal counterparts. New technologies may further life expectancy than their more equal counterparts. New technologies may further
concentrate benefits and value in the hands of the already wealthy. Those who didn't benefit from earlier industrialisation risk being left even further behind'. 
should accompany technological developments and utilisations should always ask whether values and intentions are taken into account.

- The kind of questions that should be asked are wideranging. Ellul's 76 questions are in my opinion, extremely helpful in this regard, covering ecological, social, practical, ethical, vocational, metaphysical, political and aesthetic considerations. ${ }^{7}$

If these wide-ranging issues are combined with specific ethical considerations on medical and pharmaceutical technology, communication technology, genetic engineering, stem cells and therapeutic cloning, nanotechnology, genetically modified crops, energy technology and human artificial intelligence, vast fields can open up that are deeply challenging and need to be addressed in a responsible manner simply because - as stated above - technological utilisation and developments imply agency. And agency can and should be influenced, if not guided, by theological considerations for many good reasons, especially regarding embodied personhood, human flourishing and dignity, values, enduring relationships and communal life.

I can only respond to this in a very limited and oversimplified practical (theological) manner as the first important step for addressing the overwhelming technological whirlwind. I will call my first step the Bartimaeus Effect (BE). The BE is an exegetical techno-transfiguration of the Christian Biblical text of Mark 10:46-52 (Bartimaeus' Story) as a hermeneutical tool to tentatively direct the probable wicked technologisation of the African soul in the light of the societal 'have nots' and 'never will haves'! Three (yes, three) miracles stand out in the story of Bartimaeus that can hermeneutically guide us in addressing the multi-facetted technological challenges of the South African society.

The beggar Bartimaeus was a social nobody, a good representative of a 'never will have'. As Jesus, the disciples and a following crowd were passing by, he started shouting: 'Have mercy on me, Jesus, Son of David'. He was bluntly silenced by the crowd. Then follow - in my opinion - the most important miracles of the three that will take place. Jesus heard his cries, stopped and asked the disciples to bring the man to him. The very same disciples that were part of the group of people that silenced Bartimaeus, turned on Jesus' request to him and said that they will take him to Jesus. I call it a 'Change-of-heart-miracle'. In my eyes, perhaps the most difficult response to elicit from anybody is a change of heart. From ignoring a cry, a plea for help, to attend to the cry and person of the cry. In the presence of Jesus, a second miracle occurs: The shouting crowd is now silenced as Jesus addresses Bartimaeus. The very same people that told him to 'shut up', must now keep their mouths shut as Jesus asked him: What can I do for you? I call it a 'Listening or hearing Miracle', that is, a space in which a 'nobody' (a beggar) can voice his deepest need; a space in which his human dignity is acknowledged as there

7.l follow here the insightful " 76 Reasonable questions to ask about Technology" formulated by Jacques Ellul (n.d.). is most probably - stated in very general terms - not a more disillusioning or hopeless or excluding experience as ignored or unheard pain. The crowd has to keep quiet and listen to the voice of a 'voiceless nobody'. Then follows the miracle of the healing of his eyes. And he could see. I simply call it a 'Sight-healing-miracle'.

For me, the three miracles represent specific hermetical guidelines for addressing the wide-ranging developments and utilisation of all kinds of technologies in our very vulnerable, politically and economically divided South African context. The voices of the 'have nots' and 'never will haves' must not be silenced, and every effort must be made for their very voices to be heard on every possible societal platform and to be taken seriously. ${ }^{8}$ But that will only happen, if those that are in power, or represent influential bodies within our society and communities (such as faith communities), experience 'heart-changes', that is, a willingness to turn around. To turn around themselves and to commit themselves to 'turning around' and where 'heart-changes' occur, new visions can open up, can be formulated and put to the ethical test of the technological advanced times of the Fourth Industrial Revolution we find ourselves in.

To conclude: The BE is my techno-hermeneutical translation of the 'preferential option for the poor' as has been expressed for over more than five decades of Liberation Theologies. We have to accept the ethical responsibility in our technologydriven societies by asking: What can we do to influence, to guide our societies by giving a voice to the voiceless, and to voice together new embodied perspectives for human flourishing and restoring human dignity? That to me is to 'embrace the eye or I of the Apple' as fulfilment of self-love and the love for thy neighbour and the deep willingness to welcome otherness.

\section{Acknowledgements Competing interests}

The author declares that they have no financial or personal relationships which may have inappropriately influenced them in writing this article.

\section{Author's contributions}

D.P.V. is the sole author of this research article.

\section{Ethical considerations}

This article followed all ethical standards for carrying out research without direct contact with human or animal subjects.

8.1 have integrated here in my exposition the very same plea by the Muslim scholar Ebrahim Moosa (2016:381) when he asks the following question: Could we reach a place where our engagement with technology is driven by an ethics of responsibility? His answer: 'My tentative view is that the to technology is not to be alarmist but to be good listen. One should listen and act on the best part of speech, as the Qur'an says, in other words, hear and understand: Yet, we might have to hear differently, with our bodies and understand together with our emerging culture'. 


\section{Funding information}

This research received no specific grant from any funding agency in the public, commercial or not-for-profit sectors.

\section{Data availability statement}

Data sharing is not applicable to this article as no new data were created or analysed in this study.

\section{Disclaimer}

The views and opinions expressed in this article are that of the author and do not necessarily reflect the official policy or position of any affiliated agency of the author.

\section{References}

African Union, 2015, Agenda 2063: The Africa we want, viewed 25 August 2018, from https://au.int/sites/default/files/pages/3657-file-agenda2063_popular_version_ en.pdf.

Business Tech, 2017, South Africa's middle class is smaller than we think, Wits Busines School, viewed 27 August 2018, from https://businesstech.co.za/news/wealth/ 202172/south-africas-middle-class-is-smaller-than-we-think/.

Burdett, M., 2017, Michael Burdett on theology and technology. What does God have to do with technology? Interview on 29 Nov 2017 is published in Technology, people \& religion, viewed 27 August 2018, from https://medium.com/subtleengine/theology-and-technology-2ca9dc7a7f1a.

Council for a Parliament of the World's Religions, 1993, Declaration toward a globa ethic, viewed 27 August 2018, from https://pluralism.org/document/declarationtoward-a-global-ethic/1993
Ellul, J., n.d., '76 Reasonable questions to ask about any technology', A. Novak 2016 (ed.), Defining identity and the changing scope of culture in the digital age, viewed 01 September 2018, from https://books.google.co.za/books?isbn=1522502130.

Franssen, M., Lokhorst, G.-J. \& Van de Poel, I., 2018, Philosophy of technology, The Stanford Encyclopedia of Philosophy, viewed 27 August 2018, from https://plato. stanford.edu/archives/fall2015/entries/technology.

Gill, D.W., 1998, 'Prolegomena to a theology of technology', Bridges: An Interdisciplinary Journal of Theology, Philosophy, and Science 5(3/4), 155-173

Harvey, R., 2017, The 'fourth industrial revolution': Potential and risks for Africa, National Science Technology and Innovation Information Portal, viewed 27 August 2018, from https://www.naci.org.za/nstiip/index.php/analytical-contributions/ technological-progress/40-the-\%27fourth-industrial-revolution\%27-potentialand-risks-for-africa

Heidegger, M., 1977, The question concerning technology, Die Frage nach der Technik, German. Originally published in Vorträge und Aufsätze (1954).

Herzfeld, N., 2009, Technology and religion. Remaining human in a co-created world, Templeton Press, West Conshohocken, PA.

McGinnes, D., 2018, What is the fourth industrial revolution? Salesforce Blog, viewed 27 August 2018, from https://www.salesforce.com/blog/.../what-is-the-fourthindustrial-revolution.

Moosa, E., 2016, 'Technology in Muslim moral philosophy', Journal of Religion and Health 55(2), 369-383. https://doi.org/10.1007/s10943-016-0192-0

Padgett, A.P., 2005, 'God versus technology? Science, secularity, and the theology of technology',Zygon40(3),577-584.https://doi.org/10.1111/j.1467-9744.2005.00689.x

Shaw, J., 2018, 'Illusions of freedom: Thomas Merton and Jacques Ellul on technology and the human condition', Religion and Theology 25(1), 151-154. https://doi. org/10.1111/rirt.13180

Schwenger, B., 2016, "'Heresy" or "Phase of nature"? Approaching technology theologically', European Journal of Taxonomy 25(1), 44-54.

Ware, K., 2017, 'Religion, science and technology. Interview', IEEE Technology and Science Magazine 36(1), 20-26. https://doi.org/10.1109/MTS.2017.2654283

Yauk, D., 2018, Theology of technology: Apples' I. Transpositions. Transpositions is the official blog of the Institute for Theology, Imagination, and the Arts at the
University of St Andrews, University of New Mexico Press, Albuquerque, viewed 27 August 2018, from www.transpositions.co.uk/theology-of-technologyapples-i. 